\title{
Screening for diabetic nephropathy: take your blinkers off
}

\author{
AHMED EID, SHAFIQ YUSUFF, MARIE-FRANCE KONG
}

\section{Introduction}

Proteinuria is one of several markers of kidney damage in diabetes. The excretion of specific types of protein, such as albumin or low molecular weight globulins, depends on the type of kidney disease that is present. ${ }^{1}$ One of the earliest changes in diabetes is an increase in glomerular filtration rate (GFR), or hyperfiltration, which is observed in patients with type 1 as well as many with type 2 diabetes and is accompanied by an increase in renal size. ${ }^{2}$ The next observable change is the development of albuminuria, and current UK guidance recommends annual screening with the albumin creatinine ratio $(A C R)$ to identify early kidney disease in patients with diabetes. ${ }^{3}$ Patients with diabetes with persistent microalbuminuria are at greatly increased risk for development of proteinuria (albuminuria $>300 \mathrm{mg} /$ day). However, it is important to exclude other causes of proteinuria in patients with diabetes, especially if there is no associated retinopathy. We report a case of an 81-yearold man with type 2 diabetes mellitus who presented with lower back pain and proteinuria but who had had normal/minimal microalbuminuria on his annual screening. He was diagnosed with multiple myeloma. The case highlights the importance of proteinuria in diagnosing multiple myeloma and the distinction between proteinuria in diabetic nephropathy and in multiple myeloma.

Key words: screening, diabetic nephropathy, proteinuria, albuminuria, multiple myeloma

\section{Case presentation}

An 81-year-old man with known type 2 diabetes mellitus diagnosed in 2011 and bipolar disorder, managed on lithium for the last 10 years, was admitted in August 2017 with worsening back pain and confusion. He had a history of chronic back pain since 2013. He had swelling of his right eye and was diagnosed with dacrocystitis by an ophthalmologist and had been treated with antibiotics but with no benefit. He was on insulin and his diabetes control had been good; his $\mathrm{HbA}_{1 \mathrm{c}}$ was $53 \mathrm{mmol} / \mathrm{mol}(7 \%)$ in June 2017. He had no retinopathy and no neurological deficit.

Initial investigations showed a normal serum sodium and

Department of Diabetes, University Hospitals of Leicester NHS Trust, Leicester, UK

Address for correspondence: Dr Marie-France Kong Department of Diabetes, University Hospitals of Leicester NHS Trust, Gwendolen Road, Leicester, LE5 4PW, UK.

E-mail: marie-france.kong@uhl-tr.nhs.uk

Br J Diabetes 2018;18:76-77

https://doi.org/10.15277/bjd.2018.174
Table 1 Urine protein/creatinine and albumin/creatinine ratios of patient

\begin{tabular}{llll}
\hline & $\begin{array}{l}\text { September } \\
\mathbf{2 0 1 5}\end{array}$ & $\begin{array}{l}\text { November } \\
\mathbf{2 0 1 4}\end{array}$ & $\begin{array}{l}\text { March } \\
\mathbf{2 0 1 3}\end{array}$ \\
$\begin{array}{l}\text { Urine protein/ } \\
\text { creatinine ratio } \\
\text { (normal 0-30) }\end{array}$ & $\begin{array}{l}102.0 \mathrm{mg} / \\
\mathrm{mmol}\end{array}$ & $\begin{array}{l}68.8 \mathrm{mg} / \\
\mathrm{mmol}\end{array}$ & $\begin{array}{l}54.1 \mathrm{mg} / \\
\mathrm{mmol}\end{array}$ \\
$\begin{array}{l}\text { Urine albumin/ } \\
\text { creatinine ratio } \\
\text { (normal 0.0-2.5) }\end{array}$ & $\begin{array}{l}2.8 \mathrm{mg} / \\
\mathrm{mmol} \\
\text { creatinine }\end{array}$ & $\begin{array}{l}1.7 \mathrm{mg} / \\
\mathrm{mmol} \\
\text { creatinine }\end{array}$ & $\begin{array}{l}\text { m } \\
\text { creatinine } \\
\text { crel }\end{array}$ \\
\hline
\end{tabular}

potassium, urea $4.8 \mathrm{mmol} / \mathrm{L}$, creatinine $130 \mu \mathrm{mol} / \mathrm{L}$, eGFR 49, serum albumin $46 \mathrm{~g} / \mathrm{L}$, adjusted calcium $2.86 \mathrm{mmol} / \mathrm{L}(2.2-2.6)$, phosphate $1.22 \mathrm{mmol} / \mathrm{L}$, haemoglobin $125 \mathrm{~g} / \mathrm{L}$ (130-180), normal mean corpuscular volume, lithium level normal. We could not find a serum calcium result from previous years. His eGFR in 2016 was $60 \mathrm{~mL} / \mathrm{min}$. His lumbosacral X-ray on admission showed a wedge compression fracture at L4. Hypercalcaemia secondary to lithium therapy was initially considered but excluded when the serum parathyroid hormone (PTH) level became available (0.4 pmol/L [1.6-7.5]). A myeloma screen was requested. A CT head scan, done as part of his confusion screen, showed a soft tissue lesion in the right orbit.

On reviewing his previous results, it was noted that there was a discrepancy between his urine ACR and protein/creatinine ratio (PCR) (table 1).

His serum light chains showed high free kappa light chain of $10,217 \mathrm{mg} / \mathrm{L}$ with a kappa/lambda ratio of $3,440.30$. He was referred to the haematologists. A bone marrow biopsy showed a heavy plasma population and confirmed the diagnosis of multiple myeloma. He also had a biopsy of the right orbital mass which showed plasmacytoma.

\section{Discussion}

The diagnosis of diabetic nephropathy is based on the detection of proteinuria. Most patients with diabetic nephropathy also have hypertension and retinopathy. The main diagnostic procedures in a patient with suspected diabetic nephropathy include the following:

- Measurement of urinary albumin or protein

- Measurement of serum creatinine concentration and estimation of GFR

- Measurement of blood pressure

- Ophthalmologic examination

Microalbuminuria refers to albumin excretion above the normal 
range but below the level of detection by tests for total protein. It is arbitrarily defined as the excretion of $30 \mathrm{mg} / 24$ hours of albumin in at least two of three consecutive non-ketotic sterile urine samples. There is substantial individual day-to-day variation in albumin excretion (coefficient of variation 30-50\%) and also between day and night collections. Even in the upper quintiles of so-called normoalbuminuria, however, the risk of progression of 30 to $300 \mathrm{mg} / 24$ hour, albumin is normally not detected by non-specific tests for protein (eg, Biuret reaction). The standard urine dipstick is insensitive for low concentrations of albumin that may occur in patients with microalbuminuria. In addition, the standard dipstick is also insensitive to positively charged serum proteins such as some immunoglobulin light chains. Albumin can be detected, however, by use of specific techniques such as dipstick, enzyme-linked immunosorbent assay, nephelometry and radioimmunoassay. Instead of a 24-hour urine collection, which is difficult to obtain, the albumin concentration can be determined in spot urine or, ideally, a first morning urine specimen because it correlates best with 24-hour protein excretion. The normal range is $20-200 \mathrm{~g} / \mathrm{min}$ or $20-200 \mathrm{~g} / \mathrm{mL}$. By definition, there is clinically overt diabetic nephropathy (macroalbuminuria) if the rate of albumin excretion exceeds $300 \mathrm{mg} /$ day. At this point, serum proteins other than albumin are usually excreted in the urine as well (non-selective proteinuria).

The detection of urinary albumin is a specific indication of diabetic nephropathy only if confounding factors such as fever, physical exercise, urinary tract infection, non-diabetic renal disease, haematuria from other causes, heart failure, uncontrolled hypertension and uncontrolled hyperglycaemia have been excluded. 4,5

Albuminuria is a more sensitive marker than total protein for chronic kidney disease due to diabetes, hypertension and glomerular disease, and current UK guidance recommends annual screening with $A C R$ rather than PCR to identify early kidney disease in patients with diabetes. The benefit of screening for microalbuminuria early in the course of diabetes is that it predicts a high renal and cardiovascular risk and thus allows targeted intervention.

The absence of retinopathy and discordance between urine albumin and total protein excretion should alert clinicians to consider a non-diabetes cause for the proteinuria. However, concordance of chronic kidney disease with advanced diabetic retinopathy is low in subjects with type 2 diabetes, and chronic kidney disease without advanced diabetic retinopathy is more frequent than isolated advanced diabetic retinopathy, at variance with type 1 diabetes. ${ }^{6}$

Approximately $10-20 \%$ of patients taking lithium develop hypercalcemia and hypocalciuria, and a smaller percentage have high serum PTH concentrations. Lithium increases serum total and ionised calcium and intact PTH levels within weeks, but these remain within the normal range in most subjects. Lithium can induce a continued defect in calcium-PTH regulation and normocalcemic patients can have a slightly raised serum PTH concentration and an increase in mean parathyroid gland volume. ${ }^{7}$

Findings on urinalysis in myeloma depend on the aetiology of the kidney damage:

- Myeloma cast nephropathy is characterised by the presence

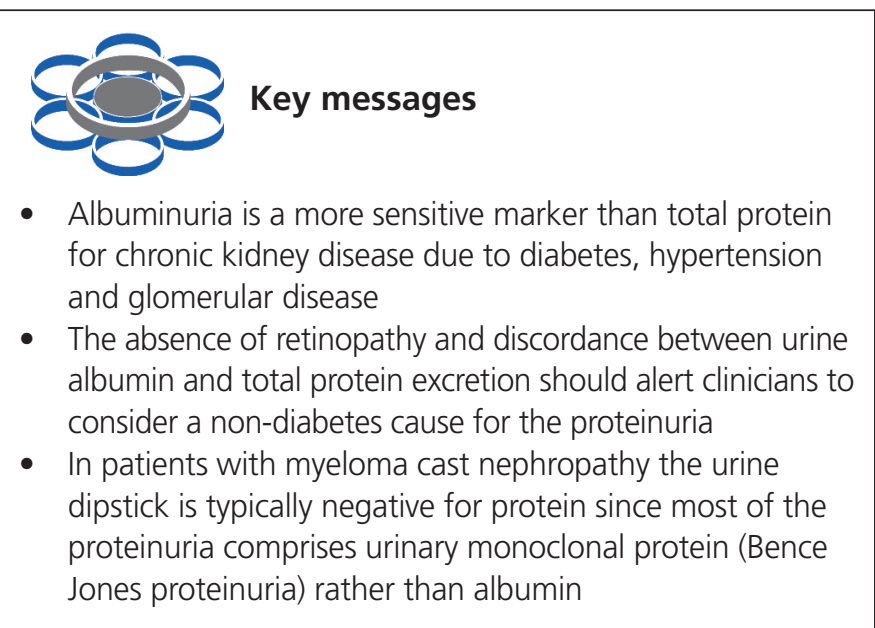

of large, waxy, laminated casts in the distal and collecting tubules; the casts are mainly composed of precipitated monoclonal light chains. The urine dipstick is typically negative for protein since most of the proteinuria comprises urinary monoclonal protein (Bence Jones proteinuria) rather than albumin.

- In contrast to myeloma cast nephropathy, renal involvement in other related plasma cell disorders (namely, AL amyloidosis and light chain deposition disease) typically present with a markedly positive dipstick for protein, since most of the urinary protein comprises albumin (nephrotic syndrome). Bence Jones proteinuria is minimal.

Our patient had an elevated PCR and negative/slightly raised ACR since 2013, and it is possible that he had undetected myeloma at the time. The discrepancy between urine albumin and urine total protein measurements should alert clinicians to consider that the patient may have a glomerular disease associated with tubulointerstitial damage - for example, myeloma.

\section{Conflict of interest None \\ Funding None}

\section{References}

1. National Kidney Foundation. KDOQI clinical practice guidelines for chronic kidney disease: evaluation, classification, and stratification. Am J Kidney Dis 2002;39(2 Suppl 1):S1-266.

2. Johnson RJ, Feehally J, Floege J. Comprehensive Clinical Nephrology. 5th edn. Philadelphia: Elsevier, 2015: Chapter 30.

3. National Institute for Health and Care Excellence. Chronic kidney disease in adults: assessment and management. NICE guideline [CG182]. 2014. https://www.nice.org.uk/guidance/cg182

4. Musso C, Javor E, Cochran E, et al. Spectrum of renal diseases associated with extreme forms of insulin resistance. Clin J Am Soc Nephrol 2006;1:616-22. http://cjasn.asnjournals.org/content/1/4/616.full

5. Redon J. Measurement of microalbuminuria: what the nephrologist should know. Nephrol Dial Transplant 2006;21:573-6. https://doi.org/10.1093/ndt/gfk014

6. Penno G, Solini A, Zoppini G, et al. Rate and determinants of association between advanced retinopathy and chronic kidney disease in patients with type 2 diabetes. Diabetes Care 2012;35:2317-23. https://doi.org/10.2337/dc12-0628

7. Mallette LE, Khouri K, Zengotita $\mathrm{H}$, et al. Lithium treatment increases intact and midregion parathyroid hormone and parathyroid volume. J Clin Endocrinol Metab 1989;68:654. 